\title{
PRESENCE OF A SPERMAGGLUTINATING FACTOR IN THE NORMAL SERUM OF RABBITS AGAINST HOMOLOGOUS SPERMATOZOA
}

\author{
M. C. PADMA* \\ Division of Dairy Chemistry, Southern Regional Station, \\ National Dairy Research Institute, Adugodi, \\ Bangalore-30, India
}

(Received 24th February 1972, accepted 1st March 1972)

While determining the presence of erythrocytic antigens on rabbit spermatozoa, it was consistently found that the normal heat-inactivated serum of individual rabbits agglutinated their own spermatozoa (Padma, 1972a). Matousek (1964) also found similar spermagglutinins in the normal sera of bulls, rams and boars against homologous spermatozoa. Edwards (1960) and Weil \& Finkler (1959) reported the complement-fixing activity of normal rabbit serum with homologous spermatozoa. Chang (1947) showed that a spermicidal factor which was thermolabile and unstable existed in the fresh sera of rabbits, guinea-pigs, rats, bulls and human beings. Freeze drying and subsequent reconstitution destroyed the factor. Smith (1949) found that normal human and goat sera caused tail agglutination of rabbit spermatozoa. She also reported that head agglutination of spermatozoa occurred with normal rabbit serum but considered this head agglutination to be non-specific and did not study the phenomenon further. Beck, Edwards \& Young (1962) and Symons (1967) by an immunoflorescence technique, Lachmann, Sell \& Spooner (1965) by mixed conglutination and Edwards (1967) and Johnson (1968) demonstrated the antispermatozoal activity of normal homologous serum. Spooner (1964) also showed that the germinal cells of the guinea-pig testis could be lysed by their own serum. On the other hand, Brown, Glynn \& Holborow (1963) in guinea-pigs, Pokorna, Vojtiskova, Rychlikova \& Chutna (1963) in mice and Mancini (1967) in guinea-pigs and humans failed to detect any type of immunological reaction between normal serum and homologous spermatozoa. In view of the contradictory reports, experiments were performed to ascertain whether the serum of normal animals shows spermagglutinin activity against homologous as well as heterologous spermatozoa.

Preparation of sperm suspensions and performance of tests were carried out within $4 \mathrm{hr}$ of collection of the semen to avoid occurrence of the spontaneous agglutination in saline reported by Smith (1949). Sera from normal rabbits were diluted up to $1 / 400$ in phosphate-buffered saline $(\mathrm{pH} 7 \cdot 1$ to $7 \cdot 2)$ and the agglutination reaction was graded arbitrarily from + to ++++ according to the intensity of reaction. In all four grades, the spermatozoa were clumped

* Present address: Department of Genetics, Osmania University, Tarnaka, Hyderabad-7, A.P., India. 


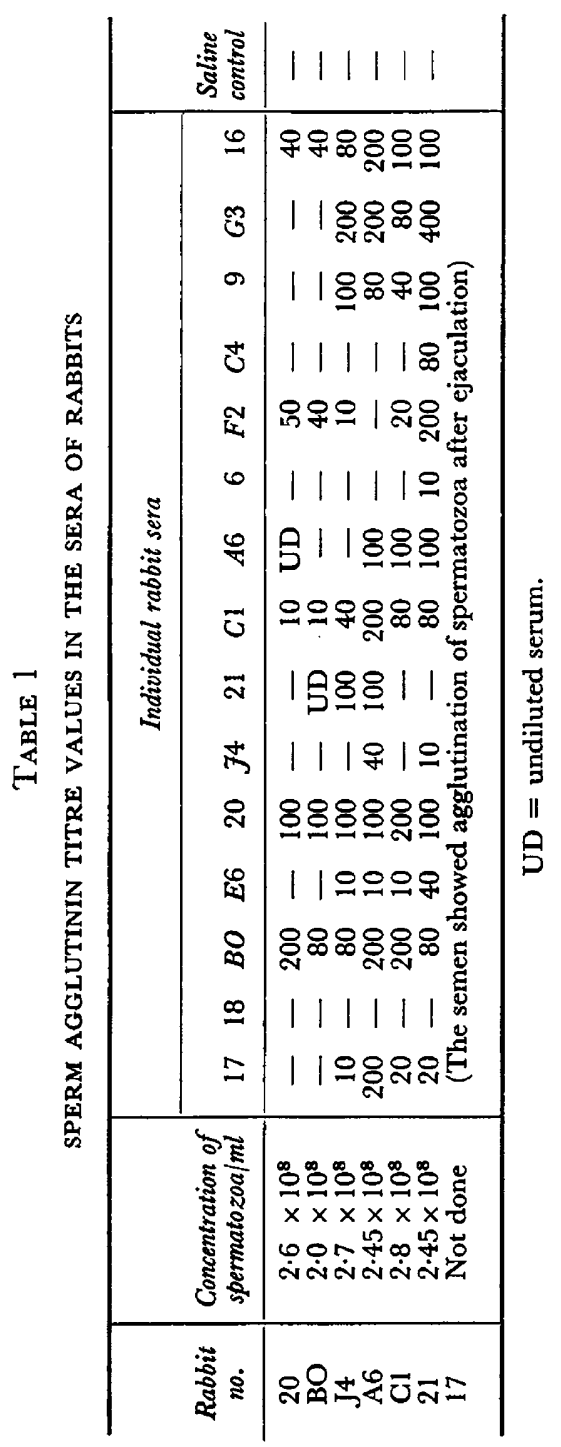


together so firmly by their heads that they were unable to move away even though their tails were actively mobile. When normal serum from fifteen rabbits was titrated against six homologous semen samples, three sera agglutinated their own spermatozoa (Rabbits BO, 20 and A6) while two sera (Rabbits $\mathrm{J} 4$ and 21) did not (Table 1). The serum of Rabbit 17 was negative to the spermatozoa of Rabbits 20 and $\mathrm{BO}$ but was positive to the spermatozoa of Rabbits J4 and A6. Rabbit 18 did not possess a serum agglutinin against any of the spermatozoa tested. No satisfactory explanation for the total absence of the spermagglutinin in this rabbit could be found. It may have been due to a genetic trait or to the presence of the agglutinin in such low concentrations that it could not be detected. Where it was present, both males and females possessed the spermagglutinin. The titre varied from $1: 10$, or lower, to $1: 400$ in fifteen sera (Table 1). The titre pattern suggested that there might be variations in

TABLE 2

REACTION OF RABBIT AND BOVINE SPERMATOZOA WITH DIFFERENT MAMMALIAN HEAT-INACTIVATED NORMAL SERA

\begin{tabular}{|c|c|c|}
\hline Undiluted sera & $\begin{array}{l}\text { Rabbit spermatozoa } \\
\text { of } A 6\end{array}$ & $\begin{array}{l}\text { Bovine spermatozoo } \\
\text { of } 2082\end{array}$ \\
\hline $\begin{array}{l}\text { Rabbit sera } \\
\text { A6 } \\
\text { BO }\end{array}$ & $\begin{array}{l}++++(\mathrm{HT})^{*} \\
++++(\mathrm{HT})\end{array}$ & $\begin{array}{l}\text { Negative } \\
\text { Negative }\end{array}$ \\
\hline $\begin{array}{l}\text { Guinea-pig serum } \\
\text { L5 }\end{array}$ & $++(\mathrm{H})$ & Negative \\
\hline $\begin{array}{l}\text { Bovine sera } \\
\quad 2082 \\
286\end{array}$ & $\begin{array}{l}\text { Negative } \\
\text { Negative }\end{array}$ & $\begin{array}{c}++++(\mathbf{H T}) \\
+++(\mathbf{H})\end{array}$ \\
\hline $\begin{array}{l}\text { Sheep serum } \\
200 \\
\text { Saline control }\end{array}$ & $\begin{array}{l}\text { Negative } \\
\text { Negative }\end{array}$ & $\underset{\text { Negative }}{+++(H)}$ \\
\hline
\end{tabular}

* HT $=$ Head and tail involvement in agglutination, or ++++ reaction; $\mathrm{H}=$ head involvement in agglutination.

sperm antigens between different rabbits. Defazio, Lewis \& Ketchel (1969) reported that variations in seminal plasma antigens existed between different human individuals. As absorption with autologous and homologous spermatozoa removed the spermagglutinin from all positive sera, further critical work alone will show whether or not fine differences of this isoantigen exist between different individual rabbits.

The spermagglutinin appeared in the serum of rabbits at the age of 50 to 60 days and was not present earlier. This observation is in agreement with that of Edwards (1960). Dialysis against distilled water in the cold did not remove the spermagglutinin. Absorption of the factor in the normal serum $(10 \mathrm{ml}$ of a $1 / 8$ dilution incubated with $1.0 \mathrm{~g}$ of the absorbant at $37^{\circ} \mathrm{G}$ for $1 \mathrm{hr}$ ) with some protein absorbants like kaolin, aluminium oxide, Fuller's earth and calcium phosphate lowered the titre of the spermagglutinin. Treatment with bone charcoal resulted in complete absorption of the factor.

Rabbit spermatozoa were agglutinated by normal inactivated guinea-pig serum but not by bovine or sheep sera (Table 2). Bovine spermatozoa were 
similarly agglutinated by normal sheep serum but not by rabbit or guinea-pig sera. Thus, the spermagglutinin would appear to be active only against the spermatozoa of members of allied genera. Characterization of this factor showed that the spermagglutinin activity is present in $\gamma_{2}$ globulin ( $\left.\operatorname{IgG}\right)$ of the serum (Padma, 1972b).

The author wishes to thank Dr K. K. Iya for suggesting the problem. She also gratefully acknowledges the kind help offered by Dr G. P. Anantha Krishnan and Dr M. Bhimsena Rao for his keen interest. Grateful thanks are also due to Mr T. P. Suresh for his help in bleeding and collection of semen in rabbits and to Dr T. V. Kumar for his help in bleeding cattle and collection of semen. She wishes to thank Professor V. Gopal Rao for critical reading of the manuscript and advice.

The research work presented here was carried out while the author was a Pool Officer (CSIR) at National Dairy Research Institute, Adugodi, Bangalore-30 from 1965 to 1967.

\section{REFERENCES}

Beck, J. S., Edwards, R. G. \& Young, M. R. (1962) Immune fluorescence techniques and the isoantigenicity of mammalian spermatozoa. 7. Reprod. Fert. 4, 103.

Brown, P. C., Glynn, L. E. \& Holborow, E. J. (1963) The pathogenesis of experimental allergic orchitis in guinea-pigs. F. Path. Bact. 86, 505.

Ghang, M. C. (1947) The effects of serum on spermatozoa. J. gen. Physiol. 30, 321.

Defazio, S., Lewis, B. K. \& Ketchel, M. M. (1969) Antigenic variations in the seminal plasma of different men. F. Reprod. Fert. 20, 29.

EDwards, R. G. (1960) Complement-fixing activity of normal serum with rabbit spermatozoa and seminal plasma. F. Reprod. Fert. 1, 268.

EDWARDs, R. G. (1967) Antibodies and fertility. Sci. Fnl, 3, 69.

JoHnson, M. H. (1968) Characterization of a natural antibody in normal guinea-pig serum reacting with homologous spermatozoa. F. Reprod. Fert. 16, 503.

Lachmann, P. J., Seld, K. W. \& Spooner, R. L. (1965) The mixed conglutination reaction. Immunology, 8, 345.

Mancini, R. E. (1967) Antispermatic antibodies in the human and animal male. Proc. VIII Conf. International Planned Parenthood Federation, p. 350. Ed. R. K. B. Hankinson. I.P.P.F., London.

MATouseK, J. (1964) Antigenic characteristics of spermatozoa from bulls, rams and boars. II. Spermagglutinin in normal and immune sera. F. Reprod. Fert. 8, 5.

Padma, M. C. (1972a) Characteristics of isoantigens of rabbit spermatozoa. I. Relationship of erythrocytic antigens to spermatozoan antigens. F. Reprod. Fert. 31, 1.

Padma, M. C. (1972b) Nature of the spermagglutinin in the normal serum of rabbits. Nature: New Biol. 238, 25.

Poxorna, Z., Vojtiskova, M., Rychlikova, M. \& Chutna, J. (1963) An isologous model of experimental autoimmune aspermatogenesis in mice. Folia biol., Praha, 9, 203.

Sмiтh, A. U. (1949) Some antigenic properties of mammalian spermatozoa. Proc. R. Soc. B, 136, 46.

SPOONER, R. L. (1964) Cytolytic activity of the serum of normal male guinea-pigs against their own testicular cells. Nature, Lond. 202, 915.

Symons, D. B. A. (1967) Reaction of spermatozoa with uterine and serum globulin determined by immunofluorescence. F. Reprod. Fert. 14, 163.

Weir, A. J. \& Finkler, A. E. (1959) Isoantigenicity of rabbit semen. Proc. Soc. exp. Biol. Med. 102, 624. 